\title{
A visual semiotic analysis of multicultural values in an Indonesian English textbook
}

\author{
Filza Isnaini*, Budi Setyono, Sugeng Ariyanto \\ Department of English Education, Faculty of Teacher Training and Education, University of Jember Jalan Kalimantan \\ No. 37, Kampus Tegalboto, Jember, Jawa Timur, 68121, Indonesia
}

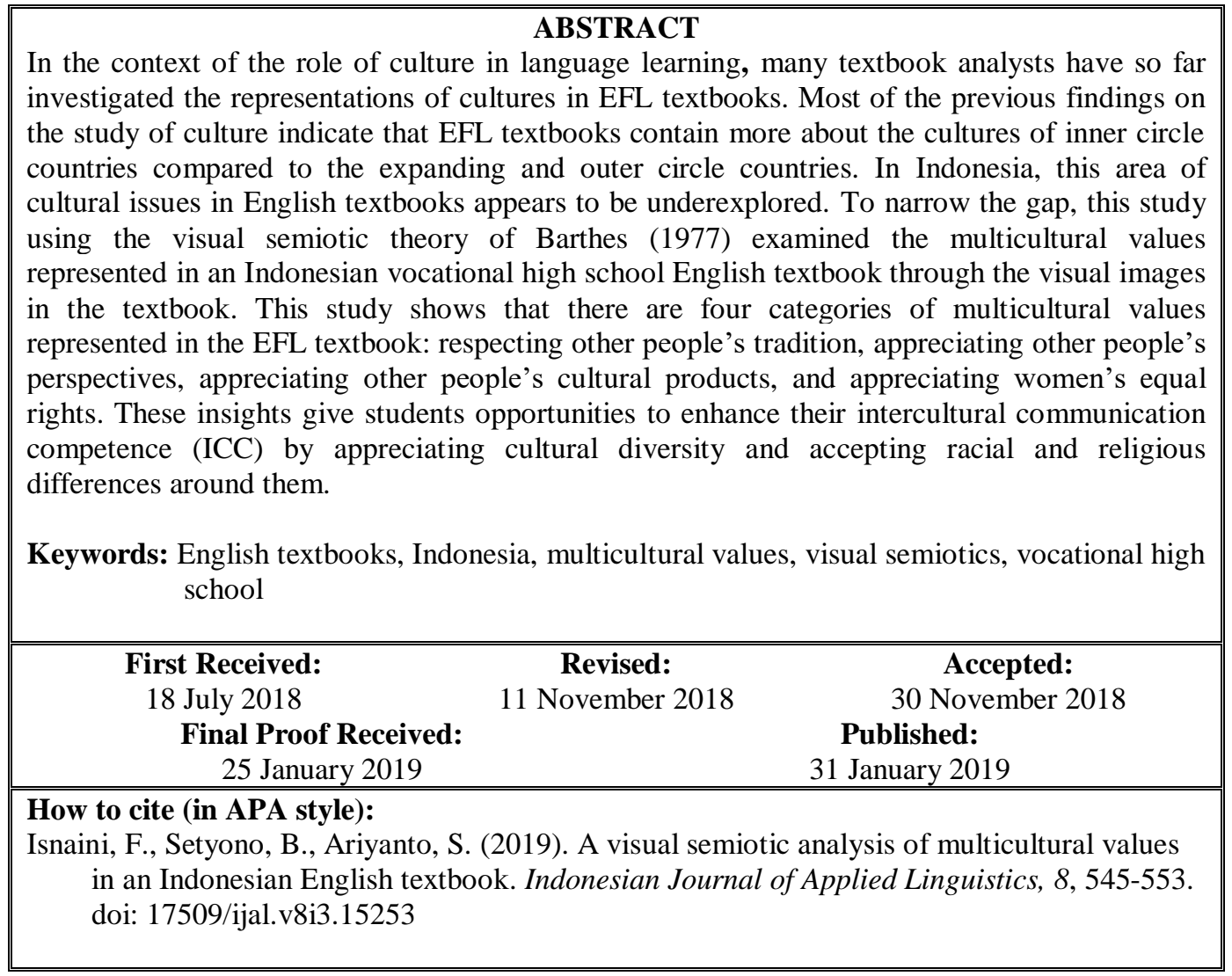

\section{INTRODUCTION}

Today English is being used more widely than ever before. The language is not only used in the inner circle countries, but also other countries outside the inner circle such as China and Korea. Pertaining to this status of English as an international language, Jenkins (2006) claims that EFL learners have higher chances to communicate with other non-native English speakers than native speakers of English. In this case, EFL learners' understanding of native and non-native English speakers' cultures constitutes an essential factor to support an effective flow of communication. Consequently, English textbooks as one of the main resources of English language teaching (ELT) in the classroom need to provide EFL learners with adequate multicultural materials through texts and images that are rich in an exposure of non-native English cultures. The deficiency of non-native cultural perspectives may create a gap for EFL learners who want to improve their intercultural competence and target language skills (Shin, Eslami, \& Chen, 2011).

The issue of cultural studies in EFL textbooks has been investigated for the past ten years in different EFL countries, focusing on different aspects of culture, and applying different tools of analysis. Of the eleven studies reviewed, three of them were conducted in Iran, two in Taiwan, while the others were conducted in Uganda, Japan, Botswana, South Korea, Spain, and a few Asian countries. The specific issues being investigated were cultural domination or cultural bias

\footnotetext{
* Corresponding Author

Email: filzaisnaini@gmail.com
} 
(Magogwe, 2009; Song 2013; Yamada, 2010), cultural elements (Bahrami, 2015; Tajeddin \& Teimournezhad, 2014), cultural background and presentation (Dastjerdi \& Samian, 2011; Johannessen, 2014; Shin et al., 2011), intercultural content and understanding ( $\mathrm{Su}, 2014)$, integrated culture (Ke, 2012), and lexical availability (Alonso \& Pento, 2016). However, the findings of those previous studies showed that most of the textbook contents are still dominated by inner circle cultural contents, instead of the learners' cultures (e.g., Shin et al., 2011). In addition, dealing with the education levels of the EFL textbooks analyzed, eight researchers analyzed high school EFL textbooks, and three others investigated college EFL textbooks in other countries. Therefore, this study is an attempt to fill in the study gap by exploring the multicultural values in vocational high school's EFL textbooks applying visual analysis (which is not used in the previous studies). The main reason is image tends to provide rich and accurate information about the cultural values, and the appropriate method to analyze such images is visual semiotic analysis, a specific sub-domain of semiotics analyzing the way visual images communicate a message. Leeuwen (2001) states that Barthian visual semiotics has layers of meaning as its key idea to investigate what, or who is being depicted and what ideas and values are expressed through what and how the image is represented.

The present study analyzed visual images that provide information about giving respects to other people's traditions or ways of life, perspectives, cultural products, and gender roles. This research focuses on answering one single research question: "What multicultural values are represented in vocational high school English textbook published by the Ministry of Education and Culture of the Republic of Indonesia?"

\section{The importance of cultures in English language learning}

It is an established fact that language and culture are inseparable. Liu (2017) claims that language is a major carrier and medium of cultural communication and transmission, and therefore in learning foreign language learners need to understand and be aware of the target language (TL) culture to achieve effective communication. Due to the wider use of English as an international communication medium, the main goal of English language teaching (ELT) has shifted from communicative competence to intercultural communicative competence (hereafter ICC). ICC demands one's ability to communicate appropriately and effectively in intercultural interaction situations (Chen \& Starosta, 1997). To gain ICC, EFL learners have to learn both the cultures of native English speakers and non-native English speakers because in the multilingual outer circle countries English is used a tool to express and impart local traditions, conventions and cultural values (Xiaoqiong \& Xianxing, 2011). The exposure of cultural knowledge and practice is essentially required in English language learning in order to improve learners' intercultural communicative skills and adopt an intercultural identity (Sercu, 2010). Therefore, cultures play an essential role in English language learning because it will help learners aware of their own culture and others to achieve ICC.

\section{Conceptualizing multicultural values in EFL textbooks}

To understand the concept of multicultural values in EFL textbooks, it is imperative to make sense of the meanings of culture and value. Culture embodies a broad and complex concept to define. Brown (2000) defines culture as "the ideas, customs, skills, and arts and tools that characterize a given group of people in a given period of time". Thus, as summarized by Moran (2001) culture consists of five dimensions: products, practices, perspectives, persons, and communities.

Besides understanding the concept of culture, the concept of values needs clarification. According to Dewey (1938), values deal with things, beliefs, actions, emotions, and attitudes, which are found acceptable, desirable, and even praiseworthy to the individual, society, or both. Therefore, based on the experts' definitions about culture and values, this study conceptualizes multicultural values as values that respect, appreciate, and tolerate the cultures of peoples from different ethnic, religious, political, economic, social, and cultural backgrounds living in different geographical areas.

The present study analyzed images (i.e. pictures, photographs, diagrams) that contain explicit and implicit messages about multicultural values, namely respecting other people's traditions, appreciating other people's perspectives, appreciating other people's cultural products, and appreciating women's equal rights.

In their research about culture-related content in EFL textbooks, Kim and Park (2015) cited in Cortazzi and Jin's (1999) proposed three sources of cultural information to be included in language textbooks such as target culture materials (TC), source culture materials (SC), and international culture materials (IC). The following years, Chao (2011) added two other categories of Cortazzi and Jin's (1999) main categories of culture, such as Intercultural Interaction (ICI) and Universality across Culture (UC). The present study uses Chao's framework (2011) of the main categories of culture in analyzing the multicultural values in order to categorize the culture represented through the images used in the EFL textbook.

\section{Images in textbooks}

Similar to textual materials, the use of images in textbooks also needs to be taken into account. Indeed, icons such as cartoons and pictures play a vital role and have a significant contribution to foreign language learning (Erfani 2012; Sert, 2006). Erfani's study (2012) on the use of pictures in English for Specific Purposes (ESP), found that foreign language students' awareness was accelerated through the combination of pictures that 
present the cultural contents and target language skills. This empirical finding shows that images in textbooks can help language learners improve their inter-cultural awareness through what and who is being depicted in the pictures and the multicultural values represented in the pictures.

\section{Previous studies on cultures in EFL textbooks}

To identify studies on the issue of cultures in EFL textbooks, seven relevant articles published in reputable international journals have been reviewed. Magogwe (2009) examined whether the cultural bias in Botswanan textbooks affects the students' motivation in learning English. The study reported that this issue does not affect the attitude and motivation of the students to learn English. In Japan, Yamada (2010) analyzing cultural biases in junior and high school English textbooks reported that the textbooks published in the 1980s focused more on American culture, while textbooks published in later years moved its focus on Japanese culture. In line with this, Shin et al. (2011) who analyzed 25 ELT textbooks used in several Asian countries reported that the cultures of inner circle countries are more dominant compared to those of outer/expanding circle countries. It indicates that the cultures of inner circle countries are more highly valued than those of outer and expanding circle countries.

In South Korea, Song (2013) who analyzed cultures in EFL textbooks reported that American cultures still dominate compared to the cultures of the outer circle countries (e.g., South Africa, Bangladesh) and expanding circle nations (e.g., Nepal, Jordan) got a little space. In an attempt to identify the types of cultures in Chinese EFL textbooks for the university level, Liu and Laohawiriyanon (2013) reported that the textbooks were dominated by target cultures (i.e., the cultures of English-speaking countries where English is spoken as a first language), while international target cultures (i.e., the cultures of English-speaking or nonspeaking English counties where English is not used as a first language) and source cultures (i.e., learner's own cultures) occupied a very small percentage.

In evaluating English textbooks for middle school students supporting multicultural perspectives, a study by Kim and Park (2015) in South Korea found that there are imbalances in the representation of culture-related contents in terms of cultural dimensions, cultural categories, and cultural themes. It indicates that intercultural interaction (ICI) was seriously underrepresented in English textbooks. In Colombia, Rodriguez (2015) who examined the cultural contents in EFL textbooks found that the communicative textbooks used in undergraduate language programs at some universities and other EFL settings mostly lack elements of deep culture that might help learners develop ICC. The results of those three studies showed that most of EFL textbooks do not adequately contain multicultural values needed to develop EFL learners' ICC.

Based on the literature review above, it is evident that studies of culture in EFL textbooks is one of the trending topics discussion in a number of international journals on education for the past ten years. However, multicultural values analysis conducted in vocational high school's EFL textbooks remains underexplored. In order to fill in the gap of the previous studies, the present study analyzed visual images that provide information about multicultural values in vocational high school EFL textbooks using the visual semiotics of Barthes (1977).

\section{METHOD \\ Data of the study}

The focus of this study is to analyze the multicultural values in an EFL textbook used in vocational high school published by the Ministry of Education and Culture. The textbook entitled Bahasa Inggris SMA/MA $S M K / M A K$ Kelas $X$ [English for High School/Islamic High School / Vocational High School/Islamic Vocational High School] is written based on the 2013 English Curriculum and contains 15 chapters, 220 pages. The main reason for analyzing the multicultural values in the textbook is because images tend to provide rich and accurate information about cultural values. The English textbooks for vocational high school are assumed to reflect the target of the 2013 English curriculum, in particular, the attainment of multicultural understanding as an important component in language learning. The visual images containing multicultural values (i.e., respecting other people's traditions, appreciating other people's perspectives, appreciating other people's cultural products, and appreciating women's equal rights) were selected purposively to answer the research questions.

\section{Tools of analysis}

The present study analyzed visual images that provide information about multicultural values in vocational high school EFL textbooks by using the visual semiotics of Barthes. Barthes (1977) argues that there are two layers in the visual semiotics' layering of meaning. The first layer is denotation that explains what and who is being depicted in the picture; the second layer is a connotation that explores the ideas and values expressed through what is represented, and how it is represented in the picture. This study used both layers to analyze the multicultural values represented in the images provided in the EFL textbook used in vocational high school, in order to reveal what those images represent and how the ideas and values are represented in the images.

\section{Procedures of analysis}

To analyze images that contain multicultural values in EFL textbook, a number of steps were taken. First, the images were identified in terms of acts which respect other people's traditions, appreciate other people's perspectives, appreciate other people's cultural products, and appreciate women's equal rights throughout the chapters in the textbook. Second, the identified pictures were coded based on the four categories, i.e., ROPT 
(respecting other people's traditions), AOPP (appreciating other people's perspectives), AOPCP (appreciating other people's cultural products) which are related to products, and AWER (appreciating women's equal rights). Those categories were connected to the five dimensions of culture as summarized by Moran (2001): ROPT represents cultural dimensions of practices, AOPP represents cultural dimensions of perspectives, AOPCP represents cultural dimensions of practices and products, and AWER represents cultural dimensions of communities. Third, the pictures were selected purposively for analysis because they met the criteria for analysis, i.e., containing implicit and explicit messages about multicultural values as mentioned before, that is closely related to Moran's (2001) five dimensions of culture and Chao's framework (2011) of cultural categories. In this present study, Source Culture (SC) refers to Indonesian culture, Target Culture (TC) refers to English-speaking countries (Australia, Canada, Ireland, New Zealand, the UK, and the USA), and International Culture (IC) includes cultures of all countries in the world (European countries, countries in Latin America, Africa, and Asia) except for Indonesian and Englishspeaking cultures. The fourth step was describing and interpreting the results of the analysis. The final step was a discussion of the results of analysis by comparing and contrasting them to related theories and findings of previous studies.

\section{FINDINGS AND DISCUSSION}

In this study, the analyses of the multicultural values represented in images were undertaken by using the visual semiotic theory of Barthes (1977). Each group of pictures was analyzed using two layers of meaning (i.e., what is described in the picture or who is described in the picture? and what are the ideas and values expressed behind the pictures?). Because of space limitation, from the 15 images that contained multicultural values selected in the textbook (see Table 1), four pictures representing each category of multicultural values (as listed in Table 1) were analyzed. The four images stipulated to be analyzed were located in: (a) Unit 1: Talking about Self, Task 2, Introduction Game-Party Time, p. 17; (b) Unit 5: Let's Visit Niagara Falls, Speaking section, p. 77; (c) Unit 1: Talking about Self, Task 2: Introduction GameParty Time, p. 17; (d) Unit 1: Talking about Self, Learning objective, p. 1 .

Table 1. Visual data of multicultural values in the textbook

\begin{tabular}{|c|c|c|c|c|}
\hline Unit & Theme & Description & Location & $\begin{array}{c}\text { Multicultural values being } \\
\text { represented }\end{array}$ \\
\hline Unit 1 & Talking about Self & $\begin{array}{l}\text { People standing in line to take the } \\
\text { foods in a party }\end{array}$ & $\begin{array}{l}\text { Task 2: Introduction } \\
\text { Game-Party Time, p. } 17\end{array}$ & $\begin{array}{l}\text { ROPT (respecting other } \\
\text { people's traditions) }\end{array}$ \\
\hline Unit 1 & Talking about Self & $\begin{array}{l}\text { An illustration of two people having } \\
\text { a conversation over Jepara's } \\
\text { engraving }\end{array}$ & $\begin{array}{l}\text { Task 2: Introduction } \\
\text { Game-Party Time, p. } 17\end{array}$ & $\begin{array}{l}\text { AOPCP (appreciating other } \\
\text { people's cultural products) }\end{array}$ \\
\hline Unit 1 & Talking about Self & $\begin{array}{l}\text { An illustration of a female student } \\
\text { wearing hijab }\end{array}$ & $\begin{array}{l}\text { Learning objective, } \\
\text { p. } 1\end{array}$ & $\begin{array}{l}\text { AWER (appreciating } \\
\text { women's equal rights) }\end{array}$ \\
\hline Unit 1 & Talking about Self & $\begin{array}{l}\text { A photograph of a female student in } \\
\text { a library }\end{array}$ & Jigsaw, p. 3 & $\begin{array}{l}\text { AWER (appreciating } \\
\text { women's equal rights) }\end{array}$ \\
\hline Unit 2 & $\begin{array}{l}\text { Congratulation and } \\
\text { Complementing } \\
\text { Others }\end{array}$ & $\begin{array}{l}\text { An illustration of two women } \\
\text { dressing in different style }\end{array}$ & $\begin{array}{l}\text { Task 2: Complementing } \\
\text { dialog, p. } 33\end{array}$ & $\begin{array}{l}\text { AWER (appreciating } \\
\text { women's equal rights) }\end{array}$ \\
\hline Unit 5 & $\begin{array}{l}\text { Let's Visit Niagara } \\
\text { Falls }\end{array}$ & $\begin{array}{l}\text { Two men having a conversation of } \\
\text { the most interesting experience }\end{array}$ & Speaking section, p. 77 & $\begin{array}{l}\text { AOPP (appreciating other } \\
\text { people's perspectives) }\end{array}$ \\
\hline Unit 5 & $\begin{array}{l}\text { Let's Visit Niagara } \\
\text { Falls }\end{array}$ & $\begin{array}{l}\text { A group of students sits in a circle to } \\
\text { discuss something }\end{array}$ & Speaking section, p. 79 & $\begin{array}{l}\mathrm{AOPP}(\text { appreciating other } \\
\text { people's perspectives) }\end{array}$ \\
\hline Unit 8 & My Idol & $\begin{array}{l}\text { A photograph of an international } \\
\text { female singer }\end{array}$ & Warmer, p. 109 & $\begin{array}{l}\text { AWER (appreciating } \\
\text { women's equal rights) }\end{array}$ \\
\hline Unit 11 & Cut Nyak Dhien & A portrait of Cut Nyak Dhien & $\begin{array}{l}\text { Reading Comprehension, } \\
\text { p. } 145\end{array}$ & $\begin{array}{l}\text { AWER (appreciating } \\
\text { women's equal rights) }\end{array}$ \\
\hline Unit 13 & Malin Kundang & $\begin{array}{l}\text { A group of students having a } \\
\text { discussion when doing a group work }\end{array}$ & $\begin{array}{l}\text { Task 2: Writing section, } \\
\text { p. } 179\end{array}$ & $\begin{array}{l}\text { AOPP (appreciating other } \\
\text { people's perspectives) }\end{array}$ \\
\hline Unit 12 & Issumboshi & $\begin{array}{l}\text { The portraits of the grandfather in a } \\
\text { Japanese folk tale entitled } \\
\text { Issumboshi }\end{array}$ & $\begin{array}{l}\text { Task 1: Reading } \\
\text { comprehension, p. } 157\end{array}$ & $\begin{array}{l}\text { AOPCP (appreciating other } \\
\text { people's cultural products) }\end{array}$ \\
\hline Unit 12 & Issumboshi & $\begin{array}{l}\text { The portraits of the princess in a } \\
\text { Japanese folk tale entitled } \\
\text { Issumboshi }\end{array}$ & $\begin{array}{l}\text { Task 1: Reading } \\
\text { comprehension, p. } 158\end{array}$ & $\begin{array}{l}\text { AOPCP (appreciating other } \\
\text { people's cultural products) }\end{array}$ \\
\hline Unit 13 & Malin Kundang & A portrait of Malin Kundang's stone & Warmer section, p. 170 & $\begin{array}{l}\text { AOPCP (appreciating other } \\
\text { people's cultural products) }\end{array}$ \\
\hline Unit 13 & Malin Kundang & A photograph of Rumah Gadang & Warmer section, p. 170 & $\begin{array}{l}\text { AOPCP (appreciating other } \\
\text { people's cultural products) }\end{array}$ \\
\hline Unit 13 & Malin Kundang & $\begin{array}{l}\text { An illustration scene when Malin } \\
\text { Kundang despised his mother }\end{array}$ & Warmer section, p. 170 & $\begin{array}{l}\text { AOPCP (appreciating other } \\
\text { people's cultural products) }\end{array}$ \\
\hline
\end{tabular}




\section{Respecting other people's traditions}

The picture that represents "Respecting other people's traditions (ROPT)" is in Unit 1: Talking about Self, Task 2: Introduction Game-Party Time, p. 17). The photograph is about a group of people who are patiently waiting for their turns to take food from the buffet in a formal event.

Figure 1 is available in Chapter 1 denotatively shows a picture of a group of people dressed up formally in a formal event and they stand in line, which portrays a gesture of patience in waiting for their turn, beside the table full of various kinds of foods. As a visual semiotic resource, connotatively this image expresses an act of respecting each other by standing in line in order to get the food. The cultural category of this picture is universality across culture (UC) because taking turns to take food when having a buffet for a party is general knowledge/content that is not specified to any particular culture or country.

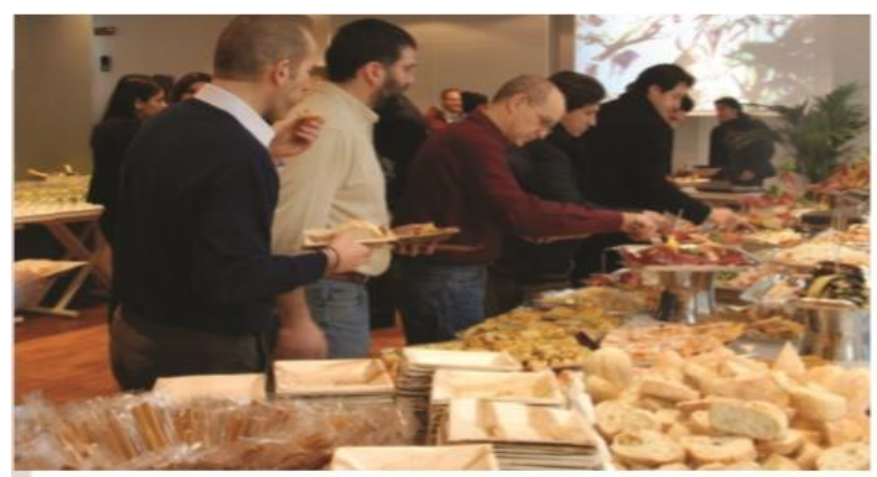

Source: http://www.spazioblendtower.it/spazioblend-tower-sala-eventi/

Picture 1.5

Figure 1. People standing in line to take food in a party

Ribeiro (2016) states that teacher can develop the students' ICC (Intercultural Communicative Competence) by establishing their ability to understand the world by searching and organizing information to make sense of evidence related to other cultures as well as their own. Therefore, in order to increase students' intercultural awareness through pictures, in this case stimulating the students' curiosity to know more about the Italian culture, which can be started by visiting the source of the picture as mentioned and the teacher should give more elaboration of the previously given questions in the textbook. The teacher can ask the students to identify the variety of foods shown in the picture or explore the variety of Italian foods usually served in a dinner party. After collecting the information needed, the teacher can ask the students to elaborate furthermore about the differences and/or the similarities they found between Indonesian and Italian parties from the picture in terms of food as a cultural product.

\section{Appreciating other people's perspectives}

Appreciating other people's perspectives (AOPP) are represented through an illustration of two men talking about the most exciting experience, and two images about a group work which represents an ideal discussion with each of the members take turns in talking and listening to appreciate each other's perspectives. However, through the limitation of the space, this section only discusses one of the visual representations of AOPP. Figure 2 is one of the illustrations that represents AOPP is available in Unit 5: Let's Visit Niagara Falls, Speaking section, p. 77.

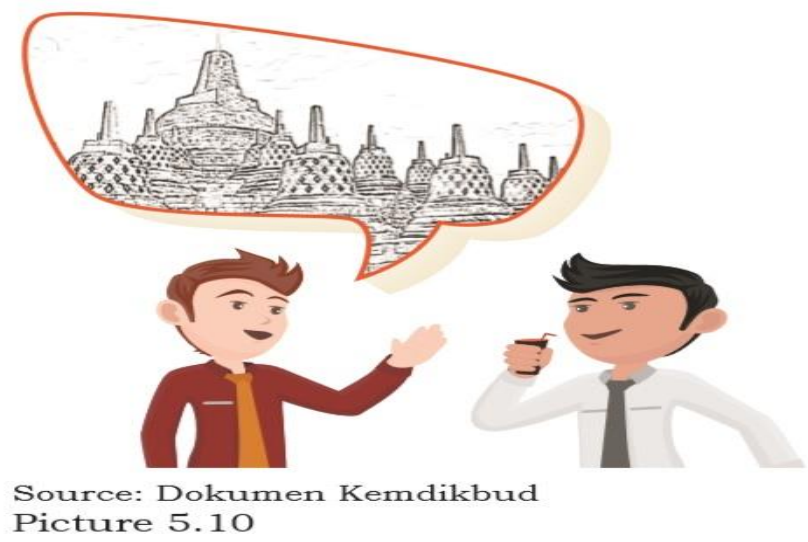

Figure 2. Two men having a conversation about their most interesting experiences. 
Figure 2, the illustration in Chapter 5, denotatively illustrates two men, one of whom has light brown hair with a brighter complexion and the other one has black hair and dark skin. The variety of their hair and skin colors depicts the socio-cultural phenomena in Indonesia and represents cultural diversity and acceptance towards racial tolerance. The characters' illustration shows that they are dressed up formally with shirts and ties of different colors, as well as neat hair, indicating that they are office workers.

The picture indicates that the man in the red shirt with a dialogue bubble with Borobudur temple on it is telling the man in the white shirt about his interesting experience in visiting the Borobudur temple. His hand gesture shows that he is eager to share his experience, instead of asking for information related to the topic. The man in the white shirt is smiling while listening to the explanation, which means that he enjoys the story being told about. Although he is holding a glass of beverage, instead of being distracted by it, he puts all of his attention to listen to his friend's experience. The gesture of the man in the white shirt shows an act of respecting other people's perspectives by giving full attention and listening to his friend's experience in visiting the Borobudur temple. As a visual semiotic resource, this picture shows multicultural values of AOPP because it represents an act of appreciation of other people's perspectives about someone's interesting experience. Denotatively, its culture is categorized as a source culture (SC) because the image's content is specified to a source culture or country that is the Borobudur Temple that is located in Indonesia.

This picture comes with a speaking task that asks the students to work in pairs to have a conversation about their interesting experiences. On the other hand, the teacher can develop intercultural competence learning by giving several cases related to the multicultural values of AOPP, in the form of asking the audience to analyze their friends' gestures during the role-playing performance, whether or not the students show gestures of AOPP and how they show acts of appreciation in the conversation.

Assignments in the form of case studies can help students to develop their observational skills about public portrayals of cultures. Observational skills play an essential role in intercultural competency that encompasses a broad array of knowledge, skills, and habits of the mind (Deardorff, 2009). Moreover, in designing students' transformational learning, Namaste (2017) states that students need to be intellectually curious, seek substantiated answers, and suspend judgment in valuing others in order to enhance their ICC.
Appreciating other people's cultural products
Appreciating other people's cultural products (AOPCP) is represented through various kinds of images. An illustration of two people having a conversation over Jepara's engraving represents an act of appreciating a cultural product from Jepara. The portrait of the grandfather and the princess in a Japanese folk tale entitled Issumboshi to show an act of appreciating international culture's product. A portrait of Malin Kundang's stone, Rumah Gadang, and an illustration scene when Malin Kundang despised his mother as a form of appreciating the source culture. One of the images was chosen to be discussed further. The illustration in Figure 3 that represents AOPCP is available in Unit 1: Talking about Self, Task 2: Introduction Game - Party Time, p. 17.

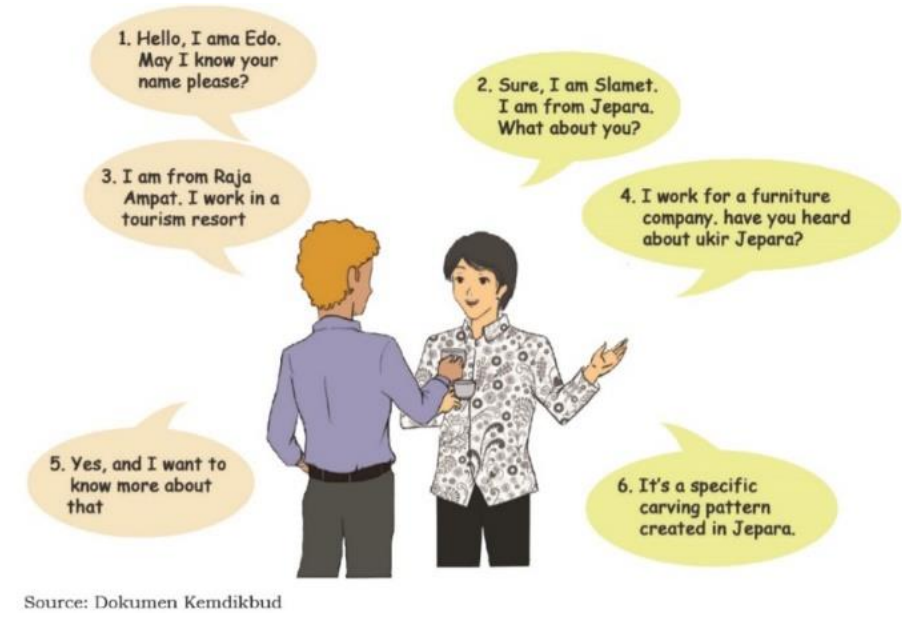

Figure 3. An illustration of two people having a conversation over Jepara's engraving.

The illustration in Chapter 1 shows an illustration of two men, one of whom comes from Raja Ampat with light brown hair with dark skin and the other one that comes from Jepara has black hair and bright skin. The characters are dressed up formally with a shirt in different color, the man with light brown hair is wearing a purple shirt and the man with black hair is wearing a shirt with a batik pattern, which shows a source cultural product, namely batik.

This image shows two people from different parts of Indonesia (Raja Ampat and Jepara) having a conversation at a party. The man from Jepara introduces a cultural product from his hometown, namely Jepara's engraving, and the man from Raja 
Ampat listening to the explanation enthusiastically by giving his full attention and through his statement that he wants to know more about it. The enthusiasm to know more about the cultural product represents an act of appreciating a cultural product from Jepara.

The illustration denotatively interprets the characters that meet in a formal occasion through the way the characters are dressed up. Connotatively, the illustration shows a contextual interpretation that refers to real-life conditions in Indonesia's heterogeneity population. The characters' depiction in this illustration through their hair and skin color and the attire that they wear, in this case the man with black hair is wearing a shirt with a batik pattern, which shows a source cultural product that is batik, conveyed a hidden message of accepting pluralism in Indonesia and ethnic and cultural diversity's acceptance. Moreover, the illustration shows multicultural values of AOPCP because it represents an act of appreciation of other people's cultural products, in this case, Jepara's engraving. Its culture is categorized as SC because the characters' identities and the ideas being depicted in the illustration show a specific culture of Indonesia, namely Jepara culture.

From this illustration, students are exposed to acts of AOPCP through the characters' dialogues. This illustration comes along with the assignment that asks students to do a role-play to re-enact the conversation in front of the class. More than re-enacting, the teacher can assign the students to do role-plays by acting as a party's guests coming from various places in Indonesia. Each student has to do research and brainstorm thoroughly before writing their script in order to obtain accurate information about the cultural products from that certain place they are going to promote. Asking the students to search and organize information and making sense of evidence related to the other cultures as well as their own will help the students' to develop intercultural communication (Ribeiro, 2016).

\section{Appreciating women's equal rights}

Appreciating women's equal rights (AWER) are represented through an illustration of a female student wearing hijab, a female student reading in a library, two women with different dress styles, a portrait of an international woman singer, and portraits of Cut Nyak Dhien, as one of the heroines in Indonesian independence. In this section, the illustration of a female student wearing hijab was chosen as one of the representative images showing the values of AWER due to space limitation and a trend on the use of hijab among female teenagers in the Indonesian school context. This illustration is placed at the beginning of the unit, in which the teacher can facilitate students to observe the socio-cultural phenomena that happen in Indonesian schools related to the form of appreciating women's equal rights. One of the illustrations that represents AWER that was analyzed may be found in Unit 1: Talking about Self, Learning objective, p. 1 (see Figure 4).

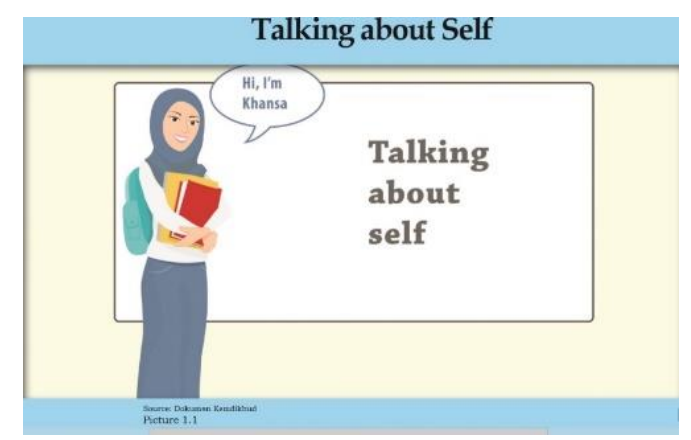

Figure 4. An illustration of a female student wearing hijab

The illustration in Chapter 1 shows an illustration of a female student wearing a high school uniform with a hijab, which represents a Muslim identity because hijab is a dress code for Muslim adult women that is required by the Holy Quran and protected by law in Indonesia. Benham and Mozahebb (2013) state that wearing hijab is part of Muslim adult women's religious identity since in Islam it is an obloigation for girls who reach nine years old or get a period to wear hijab. This illustration depicted the fact that nowadays hijab has become a trending dress code among female teenagers, also as a dressing practice in the Indonesian school context (especially, in public schools and Islamic schools). This illustration depicts a sociocultural phenomenon in Indonesia by illustrating a female student wearing a high school uniform and a hijab.
The illustration denotatively interprets the character is a Muslim female high school student through the way the character is dressed up. Connotatively, the illustration shows a contextual interpretation that refers to real-life conditions in Indonesia's socio-cultural phenomena, also as an act of appreciation towards women's equal rights. This illustration of a female student wearing hijab considers the Islamic values that hold a pivotal role as the most portrayed values in Indonesian students' social background that are dominantly related to multireligious values that acknowledge the equal opportunity for females and males to get education and employment (Ariyanto, 2018). The culture being depicted is categorized as SC because the character's identity and the image's content is specified to Indonesian culture. 
From this illustration, the teacher can lead the students to observe various socio-cultural phenomena that happen around the school in Indonesia related to the form of appreciating women's equal rights other than the right of women to get a formal education, by observing their surrounding.

Based on the result above, there are four categories of multicultural values represented through the images provided in the vocational high school EFL textbook published by the Ministry of Education and Culture of the Republic of Indonesia. Apart from the representation of multicultural values, the images in the EFL textbook also portray socio-cultural phenomena in Indonesia and interpret real-life conditions of school communities in Indonesia based on the population's heterogeneity. It gives a chance for the students to enhance their Intercultural Communicative Competence (ICC) by starting to appreciate cultural diversity and to accept racial and religious tolerance around them.

\section{CONCLUSION}

The present study has examined the four categories of multicultural values represented in a vocational high school English textbook published by the Ministry of Education and Culture of the Republic of Indonesia. The four categories of multicultural values to be analyzed are one image showing an act of respecting other people's traditions (ROPT), three images show acts of appreciating other people's perspectives (AOPP), five images show acts of appreciating women's equal rights (AWER), six images show acts of appreciating other people's cultural products (AOPCP). The findings reveal that the most represented multicultural value is that of appreciating other people's cultural products (AOPCP), whereas the multicultural value 'respecting other people's tradition (ROPT)' is represented through one image in the current English textbook. As for the cultural categories, eight images represent the source culture (SC), three images represent international culture (IC), three images represent universality culture (UC), one image represents intercultural culture (ICI), and none of it represents the target culture (TC). Therefore, it can be concluded that most of the images that represent multicultural values dominantly represent the source culture. To summarize, the findings of the present study indicate imbalanced representations of multicultural values in the textbook analyzed. None of the cultural values depicted in the textbook represents the target culture.

Therefore, authors and teachers have an essential role to overcome the uneven presentation of multicultural values and cultural sources content. As evaluators and users of EFL textbooks, English teachers should become active participants by choosing appropriate EFL textbooks, reviewing and analyzing the multicultural values and cultural sources, also giving feedback to the publishers. In order to overcome the imbalance, English textbooks should provide more images that represent multicultural values' materials that focus on ROPT to help the language learners improve their intercultural communication competence (ICC) through images. An active role from English teachers such as providing various additional activities related to the pictures given in the textbook is important to increase the use of multicultural values being depicted. This can be achieved by engaging students in comparing the differences and similarities among different cultures and countries, such as problemsolving, role-play, and/or case study may enhance students' multicultural awareness and improve their ICC. Therefore, research studies exploring multicultural values represented through images in EFL textbooks remain worthy in the future research agenda.

\section{REFERENCES}

Alonso, A. C., \& Ponte, D. C. (2016). EFL learners' cultural available lexicon: The effect of ELT textbooks. Revista de Lenguas para Fines Específicos, 22(2), 177-201.

Ariyanto, S. (2018). A Portrait of Gender Bias in the Prescribed Indonesian ELT Textbook for Junior High School Students. Sexuality \& Culture. 17(3), 1-25. doi: 10.1007/s12119-018-9512-8

Bahrami, N. (2015). Evaluating the representation of cultural elements in an in-use EFL textbook. Advances in Language and Literary Studies, 6(3), 128-137. doi: 10.7575/aiac.alls.v.6n.3p.128

Barthes, R. (1977). Image, music, text. London: Fontana Press.

Benham, B., \& Mozaheb, M. A. (2013). The depiction of men and women within Iranian high school EFL textbooks, tested against Islamic custom. Journal of Beliefs \& Values, 34(1), 100-104. doi: 10.1080/13617672.2013.760253

Brown, H. D. (2000). Principles of language learning and teaching $\left(4^{\text {th }}\right.$ ed.). White Plains, New York: Addison Wesley Longman.

Chao, T. C. (2011). The Hidden Curriculum of Cultural Content in Internationally Published ELT Textbooks: A closer look at new American inside out. The Journal of Asia TEFL, 8(2), 189-210.

Chen, G. M., \& Starosta, W.J. (1997). A review of the concept of intercultural sensitivity. Human Communication, 1(1), 1-16.

Cortazzi, M., and Jin, L. (1999). Cultural mirrors: Materials and methods in the EFL classroom. In E. Hinkel (Ed.), Culture in the second language teaching and learning, 149-176. Cambridge: Cambridge University Press.

Dastjerdi, H. V., \& Samian, S. H. (2011). Quality of Iranian EFL learners' argumentative essays: Cohesive devices in focus. Mediterranean Journal of Social Sciences, 2(2), 65-76.

Deardorff, D. (Ed.). (2009). The SAGE handbook of intercultural competence. Thousand Oaks, CA: SAGE. 
Dewey, J. (1938). Experience and education. New York: Macmillan Company.

Erfani, S.M. (2012). Pictures speak louder than words in esp, too!. English Language Teaching, 5(8), 164169. doi: 10.5539/elt.v5n8p164

Jenkins, J. (2006). The spread of EIL: a testing time for testers. ELT Journal, 60(1), 42-50. doi: 10.1093/elt/cci080

Johannessen, E. S. (2014). Constructing English as a Ugandan language through an English textbook. Language, Culture and Curriculum, 28(2) 126-142. doi: 10.1080/07908318.2014.987296

Ke, I. C. (2012). From EFL to English as an international and scientific language: Analysing Taiwan's high-school English textbooks in the period 1952- 2009. Language, Culture and Curriculum, 25(2), 173-187. doi: 10.1080/07908318.2012.683530

Kim, S. Y., \& Park , J. W. (2015). Analysis of culturerelated content in English textbooks. Linguistic Research, 32(1) 83-104. doi: 10.17250/khisli.32..201507. 005

Leeuwen, T. V. (2001). Semiotics and Iconography. In T. V. Leeuwen, \& C. Jewitt (Eds.), Handbook of Visual Analysis (pp. 92-118). New York: SAGE Publication Ltd.

Liu, J. (2017). On culture infiltration and the strategy integrated with specialty characteristics in college English teaching. English Language Teaching, 10(5), 91-96. doi: 10.5539/elt.v10n5p91

Liu, S., \& Laohawiriyanon, C. (2013). Cultural content in EFL listening and speaking textbooks for Chinese university students. International Journal of English Language Education, 1(1), 82-93. doi: 10.5296/ijele.v1i1.2850

Magogwe, J. M. (2009). The influence of cultural bias on motivation to learn English: the case of khoe primary school students in eastern Botswana. Language, Culture and Curriculum, 22(1), 1-13. doi: 10.1080/0790831080 2538315

Moran, P. R. (2001). Teaching culture: Perspectives in Practice. Australia: Heinle \& Heinle.

Namaste, N. B. (2017). Designing and evaluating students' transformative learning. The Canadian Journal for the Scholarship of Teaching and Learning, 8(3), 1-19. doi: 10.5206/cjsotlrcacea.2017.3.5

Ribeiro, S. P. (2016). Developing intercultural awareness using digital storytelling. Language and
Intercultural Communication, 16(1), 69-82. doi: 10.1080/14708477. 2015.1113752

Rodríguez, L. F. G. (2015). The cultural content in EFL textbooks and what teachers need to do about it. PROFILE Issues in Teachers' Professional Development, 17(2), 167-187. doi:10.15446/profile.v17n2.44272

Sercu, L. (2010). Assessing intercultural competence: More questions than answers. In A. Paran \& L. Sercu (Eds.), Testing the untestable in language education (pp. 17-34). Clevedon, UK: Multilingual Matters.

Sert, O. (2006). Semiotic approach and its contributions to English language learning and teaching.

Hacettepe Üniversitesi Exitim Fakültesi Dergisi, 31(1), 106-114.

Shin, J., Eslami, Z. R., \& Chen, W. C. (2011). Presentation of local and international culture in current international English-language teaching textbooks. Language, Culture and Curriculum, 24(3), 253-268. doi: $10.1080 / 07908318.2011 .614694$

Song, H. (2013). Deconstruction of cultural dominance in Korean EFL textbooks. Intercultural Education, 24(4), 382-390. doi: $10.1080 / 14675986.2013 .809248$

Su, Y. C. (2014). The international status of English for intercultural understanding in Taiwan's high school EFL textbooks. Asia Pacific Journal of Education, 36(3), 390-408. doi: 10.1080/02188791.2014.959469

Tajeddin, Z., \& Teimournezhad, S. (2014). Exploring the hidden agenda in the representation of culture in international and localised ELT textbooks. The Language Learning Journal, 43(2) 180-193. doi: 10.1080/09571736.2013.869942

Xiaoqiong, B., \& Xianxing, J. (2011). Kachru's three concentric circles and English teaching fallacies in EFL and ESL contexts. Changing English: Studies in Culture and Education, 18(2), 219-228. doi: 10.1080/1358684X.2011.575254

Yamada, M. (2010). English as a multicultural language: implications from a study of Japan's junior high schools' English language textbooks. Journal of Multilingual and Multicultural Development, 31(5), 491-506. doi: $10.1080 / 01434632.2010 .502967$ 